The International Journal of Children's Rights 


\title{
The International Journal of Children's Rights
}

\author{
Editors-in-Chief \\ Professor Laura Lundy, Queen's University, Belfast, Northern Ireland \\ Professor Helen Stalford, University of Liverpool, $U K$
}

Editor Emeritus

Professor Michael Freeman, F.B.A., University College London, UK

Managing Editor

Ruth Eldon, London, UK

Book review editor

Dr Noam Peleg, UNSW, Australia

\section{Editorial Advisory Board}

Priscilla Alderson, University of London, London, UK

Philip Alston, New York University, New York, NY, USA

Erica Burman, University of Manchester, UK

Ferán Casas, Geneva Academy of International Humanitarian Law and Human Rights, Switzerland

Alex Conte Aznar, Universitat de Girona, Girona, Spain

Matias Cordero Arce, Spain

Lee Ann Basser, La Trobe University, Melbourne, Australia

Neil Boothby, Mailman School of Public Health, Columbia University, New York, NY, USA

Paolo David, Office of the High Commissioner for Human Rights (OHCHR), Geneva, Switzerland

Ellen Desmet, Ghent University and University of Antwerp, Belgium

Jenna Gillett -Swan, Queensland University of Technology, Australia

Chris Goddard, Social Administration, Monash University, Australia

Coby de Graaf, University of Amsterdam, Amsterdam, The Netherlands

Simon Hoffman, Swansea University, Wales, UK

Katherine Hunt Federle, Ohio State College of Law, Columbus, OH, USA

Savitri Gooneskere, University of Colombo, Colombo, Sri Lanka

Olga Khazova, UN Committee on the Rights of the Child

Ursula Kilkelly, University College Cork, Ireland

Ton Liefaard, Leiden University, Leiden, The Netherlands

Anne McGillivray, University of Manitoba, Canada

Yanghee Lee, Sungkyunkwan University, South Korea

Richard Macclure, University of Ottawa, Canada

Gary Melton, University of Colorado Denver, USA

Benyam Dawit Mezmur, University of Western Cape, South Africa

Richard C. Mitchell, Brock University, St. Catharines, Ontario, Canada

Vitit Muntarbhorn, Chulalongkorn University, Bangkok, Thailand

Aoife Nolan, University of Nottingham, UK

Nigel Parton, University of Huddersfield, Huddersfield, $U K$

Noam Peleg, unsw, Australia

Ann Quennerstedt, Örebro University, Sweden

Marta Santos Pais, Special Representative on Violence against Children, United Nations, New York, NY, USA

Caroline Sawyer, Victoria University of Wellington, New Zealand

Julia Sloth-Nielsen, University of Western Cape, Belville, South Africa

Nigel Thomas, University of Central Lancashire, Preston, UK

Kay Tisdal, University of Edinburgh, Edinburgh, Scotland

John Tobin, Law, University of Melbourne, Australia

Velina Todorova, Deputy Minister of Justice, Bulgaria

Jonathan Todres, Georgia State University, Atlanta, USA

Philip Veerman, Health psychologist, Youth Intervention Team (JIT), The Hague, The Netherlands

John Wall, Religious Studies, Rutgers University, Camden, N.J., USA

This journal is peer-reviewed.

Volumes published in this journal are listed on brill.com/chil 


\title{
The International Journal of Children's Rights
}

VOLUME 30 (2022)

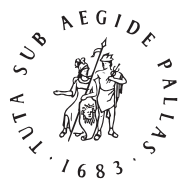 \\ B R I L L \\ NIJHOF F \\ LEIDEN | BOSTON
}


Need support prior to submitting your manuscript? Make the process of preparing and submitting a manuscript easier with Brill's suite of author services, an online platform that connects academics seeking support for their work with specialized experts who can help. Go to authorservices.brill.com/.

Brill Open Access options can be found at brill.com/openaccess.

Typeface for the Latin, Greek, and Cyrillic scripts: "Brill". See and download: brill.com/brill-typeface.

ISSN 0927-5568

E-ISSN 1571-8182

Copyright 2022 by Koninklijke Brill NV, Leiden, The Netherlands.

Koninklijke Brill NV incorporates the imprints Brill, Brill Nijhoff, Brill Hotei, Brill Schöningh, Brill Fink, Brill mentis, Vandenhoeck \& Ruprecht, Böhlau Verlag and V\&R Unipress.

All rights reserved. No part of this publication may be reproduced, translated, stored in a retrieval system, or transmitted in any form or by any means, electronic, mechanical, photocopying, recording or otherwise, without prior written permission from the publisher. Requests for re-use and/or translations must be addressed to Koninklijke Brill NV via brill.com or copyright.com.

Brill has made all reasonable efforts to trace all rights holders to any copyrighted material used in this work. In cases where these efforts have not been successful the publisher welcomes communications from copyright holders, so that the appropriate acknowledgements can be made in future editions, and to settle other permission matters.

This journal is printed on acid-free paper and produced in a sustainable manner. 